\title{
Antibacterial Activity of Pterocarpus osun L. on Multi-Drug Resistant (MDR) Escherichia coli from Wound Infections in Abeokuta, South-West Nigeria
}

\author{
Bode Ireti Shobayo', David Ajiboye 0jo, David Adejare Agboola² \\ ${ }^{1}$ Department of Microbiology, Federal University of Agriculture, Abeokuta, Nigeria \\ ${ }^{2}$ Department of Biology, Federal University of Agriculture, Abeokuta, Nigeria \\ Email: bodeshobayo@gmail.com, daojo3@yahoo.com, jareagbo@yahoo.com
}

Received 26 July 2015; accepted 12 August 2015; published 20 August 2015

Copyright (C) 2015 by authors and OALib.

This work is licensed under the Creative Commons Attribution International License (CC BY). http://creativecommons.org/licenses/by/4.0/

(c) (i) Open Access

\begin{abstract}
Pterocarpus osun L. plant has been used overtime in the indigenous system of medicine. In this study, methanol, ethanol and aqueous extracts of leaves of $P$. osun $L$. were examined against five Escherichia coli strains obtained from wounds. Antibacterial effect of the plant leaves, in the concentration of $100 \mathrm{mg} / \mathrm{ml}$, was determined using disc diffusion method. Phytochemical screening of extracts of the leaves revealed the presence of phenols, flavonoids, tannins, terpenoids alkaloids, and glycosides. Leaves extracts of $P$. osun L. showed different zones of inhibition to the Escherichia coli isolates in the different solvents used. Results from this study showed that extracts of $P$. osun $\mathrm{L}$. had broad spectrum of activity on the tested bacteria.
\end{abstract}

Keywords

Pterocarpus osun L., Antibacterial Activity, Multi-Drug Resistance, Wound

Subject Areas: Microbiology

\section{Introduction}

Pterocarpus osun L. is a deciduous leguminous tree which belongs to the family Fabaceae. It is found in African savannahs and dry forests and is also widely distributed in the tropics throughout the world. The plant is famous for producing one of the finest woods in its native region [1]. P. osun L. has several common names including Vene in French, Palissandre in Senegal, Kino in Gambia, Bani or Banuhi in Burkina Faso, Madubiya in Northern Nigeria and Osundudu in Southwest Nigeria. The species is considered to be endangered due to constant

How to cite this paper: Shobayo, B.I., Ojo, D.A. and Agboola, D.A. (2015) Antibacterial Activity of Pterocarpus osun L. on Multi-Drug Resistant (MDR) Escherichia coli from Wound Infections in Abeokuta, South-West Nigeria. Open Access Library Journal, 2: e1434. http://dx.doi.org/10.4236/oalib.1101434 
human or other pressures and any reduction in the population size is bound to enforce inbreeding and genetic bottlenecks [2].

Medicinal plants are plants containing inherent active ingredients used to cure disease or relieve pain [3]. As can be found in ethno-botanical reports, a number of plants are reputed in the indigenous system of medicine for their antidiabetic activities. Furthermore, the World Health Organization (WHO) estimates that $80 \%$ of the populations of developing countries rely on traditional medicines, mostly plant drugs, for their primary health care needs [4]. Pterocarpus spp is one of such plants which have been used for treatment of type 2 diabetes [5]. The stem bark powder in of Pterocarpus spp has also been used in treating diarrhea and the wood powder has been externally applied in the treatmentof inflammations, headache, mental aberrations, and ulcers [6]. The stem bark extract has shown to contain maximum activity against Enterobacter aerogenes, Alcaligenes faecalis, Escherichia coli, Pseudomonas aeruginosa, Proteus vulgaris, Bacillus cereus, Bacillus subtilis, and Staphylococcus aureus [7]. However, many of them remain to be scientifically established. Importantly, qualitative phytochemical analysis of Pterocarpus spp has confirmed the presence of various components, such as carbohydrates, steroids, anthocyanins, saponins, tannins, phenols, triterpenoids, flavonoids, glycosides, and glycerides [8].

Wound infection is one of the serious health problems that are caused and aggravated by the invasion of pathogenic organisms into different parts of the body [9]. In general, a wound can be considered infected if purulent materials drain from it, even without confirmation of positive cultures [10]. Bacterial contamination of wounds is an important cause of mortality [11]. Moreover, previous studies from different parts of the country showed that Pseudomonas spp, Staphylococcus aureus, Klebsiellaspp, Escherichia coli and Proteus spp are the most common pathogens isolated from wound [9].

According to the European Centre for Disease Prevention and Control (ECDC) and the Centers for Disease Control and Prevention (CDC), multi-drug resistance (MDR) is defined as non-susceptibility to at least one agent in three or more antimicrobial categories [12]. Emergence of resistance to multiple antimicrobial agents in pathogenic bacteria has become a significant public health threat as there are fewer or, even sometimes, no effective antimicrobial agents available for infections caused by these bacteria [13]. The widespread use of antibiotics, together with the length of time over which they have been available, has led to major problems of resistant pathogens in wound infections contributing to morbidity, and mortality [10].

Antibiotic resistance in E. coli has been globally identified in isolates from hospital, environmental, human and animal sources. In the last few years, the emergence and wide dissemination of $E$. coli strains showing resistance to broad-spectrum of antimicrobial agents have been reported [14]. E. coli has also been reported to be highly resistant to ampicillin, amoxicillin, tetracycline and trimethoprim-sulfamethoxazole [15]. Similarly, a high rate of reistance was observed by Escherichia coli to ampicillin according to Celebi et al. [16].

The need for new antimicrobial agents is therefore greater than ever due to the emergence of multidrug resistance in common pathogens, the rapid emergence of new infections, and the potential for use of multidrugresistant agents in bioweapons [17]. This work investigated the role of aqueous, methanol and ethanol extracts of Pterocarpus osun L. as potential antimicrobial agents against multi-drug resistant E. coli isolates from wound infections.

\section{Materials and Methods}

\subsection{Plant Materials}

The fresh leaves of Pterocarpus osun L. were collected from Ibadan, Oyo State and identified in Biological Science Department (Botany) of Federal University of Agriculture, Abeokuta, Ogun State.

\subsection{Phytochemical Analysis}

Phytochemical analysis of the extracts was carried out based on the methods described by [18]. Qualitative test were conducted on the crude extracts to examine for the presence of the alkaloids, saponins, tannins, terpenoids, flavonoids, glycosides and phenols.

\subsection{Preparation of Aqueous Extracts}

The plant leaves of Pterocarpus osun L. were washed with running tap water and then shade dried at room temperature for 15 days. Ten grams of the dried leaves were weighed, crushed directly by grinder and dipped into 
$100 \mathrm{ml}$ distilled water in a conical flask. The flask was stoppered with rubber corks and left for 2 days with occasional shaking and filtered off using sterile filter paper (Whattman No. 1). The filtrates were evaporated under reduced pressure to get a thick residue which was treated as experimental drug for the present study. The standard extracts obtained were then stored in a refrigerator at $4^{\circ} \mathrm{C}$ for antibacterial activity test [19].

\subsection{Preparation of Ethanol and Methanol Extracts}

The same procedure as above was followed for the preparation of methanol and ethanol extracts with 100\% grade of the solvents.

\subsection{Model Microorganisms}

Escherichia coli isolates (E1, E2, E3, E4 and E5) were obtained from Federal Medical Centre, Abeokuta and confirmed biochemically. The isolates were maintained on nutrient agar slants at $4^{\circ} \mathrm{C}$.

\subsection{Petri-Dishes}

Antibacterial activity of the sample (P. osun L.) was performed using disc diffusion method to determine sensitivity of the bacteria to the extracts. Discs containing dissolved plant extract were prepared using sterile Whatman filter paper No. 1 (6 mm in diameter). The discs were dried at $50^{\circ} \mathrm{C}$. Overnight cultures of each of bacterial isolate was diluted with sterile normal saline to give inoculum size of $106 \mathrm{cfu} / \mathrm{ml}$. Nutrient agar medium was prepared, sterilized, cooled and poured in to sterile petri dishes to a depth of $4 \mathrm{~mm}$ about $25 \mathrm{ml} / \mathrm{plate}$ to solidify. Pure cultures of the test organism were used to inoculate the petri dishes. This was done by spreading the inocula on the surface of the prepared nutrient agar plate using sterile cotton swabs which have been dipped in the diluted suspension of the organism. The discs were then aseptically placed evenly on the surface of the inoculation and gently pressed down to ensure contact using a pair of forceps. Negative controls were prepared using the solvents only. Tetracycline (Tet), Ampicillin (Amp), Gentamycin (Gen), Ofloxacin (Oflo) and Ceftriazone (Cef) were used as positive controls to determine the sensitivity of bacterial strain. The plates were incubated at $37^{\circ} \mathrm{C}$ for $24 \mathrm{~h}$. Antimicrobial activity was evaluated by measuring the zones of inhibition against the tested bacteria. Each assay was carried out in triplicate.

\section{Results and Discussion}

Phytochemical screening of the dry leaves of Pterocarpus osun L. using aqueous, methanol and ethanol solvents revealed the presence of bioactive compounds as shown in Table 1. Both ethanol and methanol extracts of $P$. osunL. revealed the presence of flavonoids, tannins, terpenoids, alkaloids and glycosides. Tannins and glycosides have been observed in P. osun L. stem extracts [20]. In aqueous extracts of $P$. osun L., flavonoids, terpenoids and saponins were observed. It has been reported that plants occur in varying habitats, a great magnitude of variation in the concentration and composition of phytochemical ingredients in the different parts of such plant is expected [21].

Table 1. Qualitative phytochemical screening of the extracts of Pterocarpus osun L.

\begin{tabular}{cccc}
\hline Phytochemical & Ethanol & Methanol & Aqueous \\
\hline Phenols & + & - & - \\
Flavonoids & + & + & + \\
Tannins & + & + & - \\
Terpenoids & + & + & - \\
Akaloids & + & + & + \\
Glycosides & + & + & +
\end{tabular}

$(+)$ indicates presence while $(-)$ indicates the absence of the bioactive component. 
The results in Table 2 showed that Escherichia coli E1 strain had zone of inhibition of $9 \mathrm{~mm}$ to ampicillin and $7 \mathrm{~mm}$ to gentamycin but was resistant to tetracycline, ofloxacin and ceftriazone. E3 was sensitive only to gentamycin with $6 \mathrm{~mm}$ zone of inhibition and was resistant to tetracycline, ampicillin, ofloxacin and ceftriazone. Escherichia coli E2, E4 and E5 showed no zones of inhibition to the antibiotics used in this study. Resistance of $E$. coli to tetracycline in this study agrees with a previous work carried out [22], which showed that $41 \%$ of $E$. coli isolates were resistant to tetracycline. It has also been reported that $E$. coli was resistant to tetracycline, ampicillin, gentamycin and ceftriazone [23].

Antimicrobial sensitivity profile of one hundred milligrams concentration (at a volume of $10 \mu \mathrm{l} / \mathrm{disc}$ at a concentration of $100 \mathrm{mg}^{-1}$ ) of the extracts in $100 \%$ methanol, $100 \%$ ethanol and aqueous solutions were tested. In Figure 1, the result showed that Escherichia coli E1, E3, E4 and E5 in 100\% methanol, were sensitive to Pterocarpus osun L. solvents with zones of inhibition of $11 \mathrm{~mm}, 12 \mathrm{~mm}, 13 \mathrm{~mm}$ and $10 \mathrm{~mm}$ respectively while there was no zone of inhibition in and E2. The results in Figure 2 showed that Escherichia coli E1, E3, E4 and E5 in 100\% ethanol were sensitive to Pterocarpus osun L. solvents with inhibition zone of $10 \mathrm{~mm}, 9 \mathrm{~mm}, 12$ $\mathrm{mm}$ and $11 \mathrm{~mm}$ respectively while there was no zone of inhibition in E2. In Figure 3, the results showed that Escherichia coli E1 and E3 in aqueous, were sensitive to Pterocarpus osun L. solvents with inhibition zone of 6 $\mathrm{mm}$ and $7 \mathrm{~mm}$ respectively while there were no zone of inhibition in E2, E4 and E5. Previous works have reported several Pterocarpus spp to be active against E. coli. In a previous work, it was revealed that extracts of Pterocarpus erinaceus was active against E. coli [24]. Similarly, a $12 \mathrm{~mm}$ zone of inhibition against E. coli was observed in $100 \mathrm{mg}$ methanol extracts of Pterocarpus marsupium [25].

The antibacterial activity exhibited by Pterocarpus osun L. against multidrug resistant E. coli in this study may be attributed to the presence of alkaloids, flavonoids and other bioactive compounds present in it, which individually or in combination exhibit antibacterial activity. One of the mechanisms of action of alkaloids is intercalate into cell wall and DNA of bacteria. Alkaloids have been implicated for its detoxifying and antihypertensive properties in a research carried out [26] and flavonoids are found to be effective antimicrobial substances against a wide range of microorganisms [27].

Table 2. Susceptibility pattern of the five $E$. coli isolates obtained from wound swabs to commonly used antibiotics (mm).

\begin{tabular}{cccccc}
\hline Isolates & Tet & Amp & Gen & Oflo & Cef \\
\hline E1 & $\mathrm{R}$ & 9 & 7 & $\mathrm{R}$ & $\mathrm{R}$ \\
$\mathrm{E} 2$ & $\mathrm{R}$ & $\mathrm{R}$ & $\mathrm{R}$ & $\mathrm{R}$ & $\mathrm{R}$ \\
$\mathrm{E} 3$ & $\mathrm{R}$ & $\mathrm{R}$ & 6 & $\mathrm{R}$ & $\mathrm{R}$ \\
$\mathrm{E} 4$ & $\mathrm{R}$ & $\mathrm{R}$ & $\mathrm{R}$ & $\mathrm{R}$ & $\mathrm{R}$ \\
$\mathrm{E} 5$ & $\mathrm{R}$ & $\mathrm{R}$ & $\mathrm{R}$ & $\mathrm{R}$ & $\mathrm{R}$ \\
\hline
\end{tabular}

$\mathrm{R}=$ Resistant.

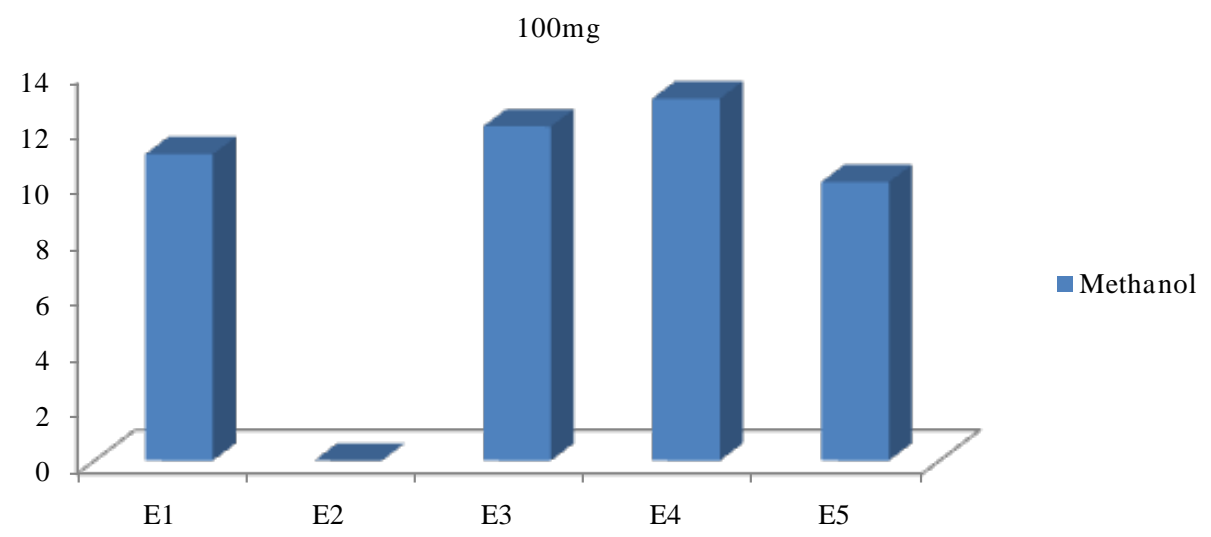

Figure 1. Zone of inhibition of Pterocarpus osun L. concentration in 100\% Methanol solvent. 


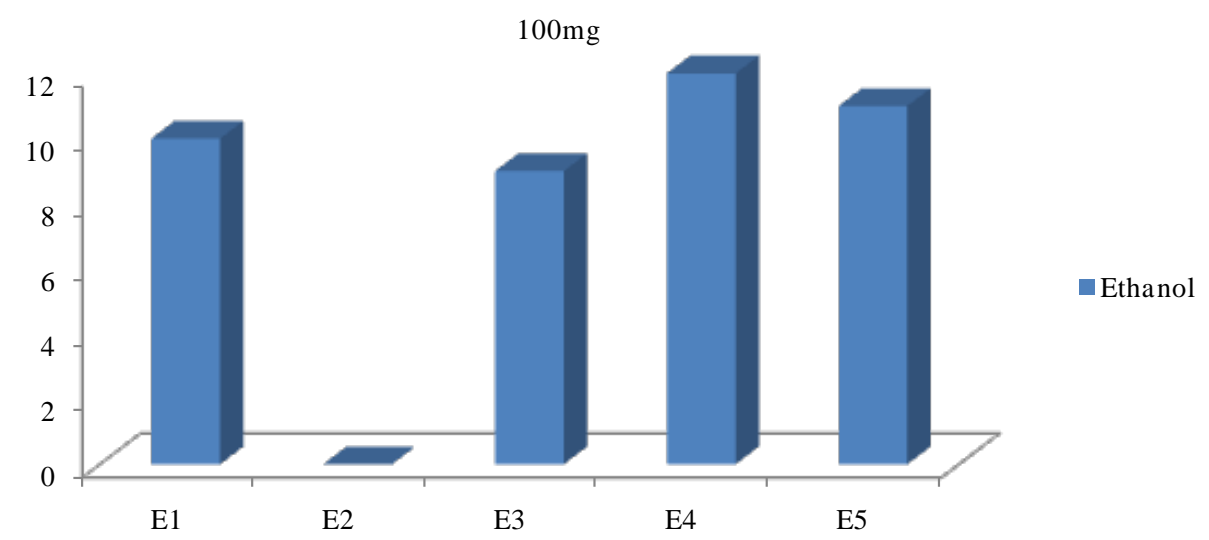

Figure 2. Zone of inhibition of PterocarpusosunL. concentration in $100 \%$ Ethanol solvent.

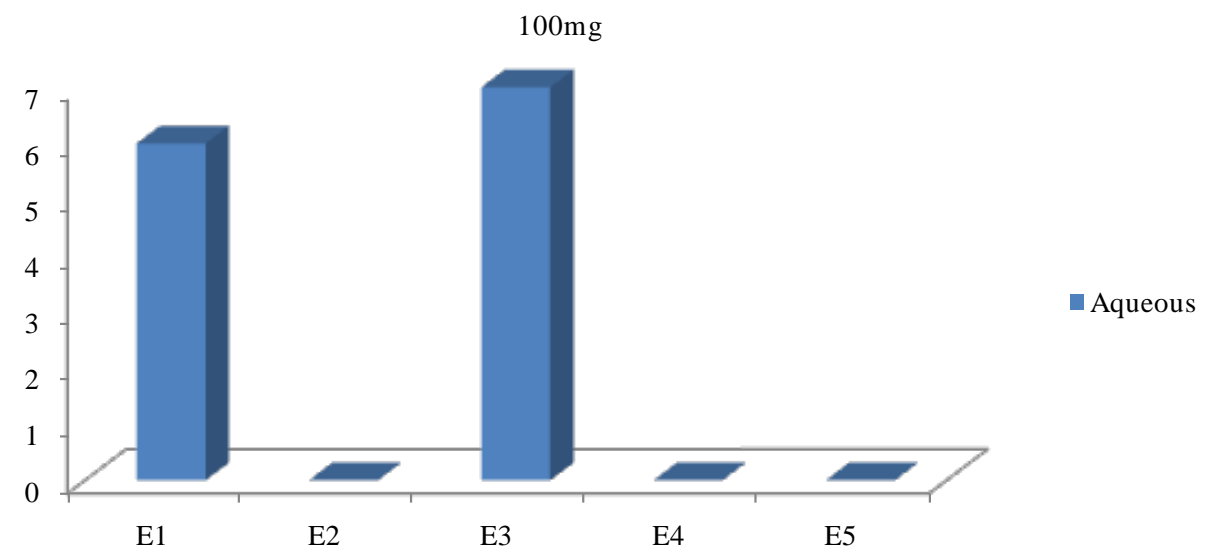

Figure 3. Zone of inhibition of Pterocarpus osun L. concentration in aqueous solvent.

\section{Conclusion}

The results of this work showed that $P$. osun L. possesses antibacterial activity against multidrug resistant $E$. coli. It is a preliminary scientific validation for the use of this plant for antibacterial activity. These results are also of interest since they have been obtained from the crude extract, which may exhibit a lower activity than the purified active compounds.

\section{References}

[1] Hutchinson, J., Dalziel, J.M. and Keay, R.W.J. (1958) Floral of West Tropical Africa. Agents for Overseas Government and Administration, London, 531.

[2] Rao, S.P. and Raju, A.J.S. (2002) Pollination Ecology of the Red Sanders Pterocarpus santalinus (Fabaceae), an Endemic and Endangered tree Species. Current Science India, 83, 1144-1148.

[3] Okigbo, R.N., Eme, U.E. and Ogbogu, S. (2008) Biodiversity and Conservation of Medicinal and Aromatic Plants in Africa. Biotechnology and Molecular Biology Reviews, 3, 127-134.

[4] World Health Organization (2003) Traditional Medicine. http://www.who.int/mediacentre/factsheett/fsl34/en/print/html

[5] Mukherjee, P.K., Maiti, K., Mukherjee, K. and Houghton, P. (2006) Leads from Indian Medicinal Plants with Hypoglycemic Potentials. Journal of Ethnopharmacology, 106, 1-28. http://dx.doi.org/10.1016/j.jep.2006.03.021

[6] Krishnaveni, K.S. and Rao, J.V. (2000) A New Isoflavoneglucoside from Pterocarpus santalinus. Journal of Asian Natural products Research, 2, 219-223.

[7] Manjunatha, B.K. (2006) Antimicrobial Activity of Pterocarpus santalinus. Indian Journal of Parmaceutical Sciences, 68, 115-116. http://dx.doi.org/10.4103/0250-474X.22982 
[8] Narayan, S., Devi, R.S. and Devi, C.S.S. (2007) Role of Pterocarpus santalinus against Mitochondrial Dysfunction and Membrane Lipid Changes Induced by Ulcerogens in Rat Gastric Mucosa. Chemico-Biological Interactions, 170, 67-75. http://dx.doi.org/10.1016/j.cbi.2007.07.005

[9] Akingbade, O.A., Balogun, S.A., Ojo, D.A., Afolabi, R.O., Motayo, B.O., Okerentugba, P.O. and Okonko, I.O. (2012) Plasmid Profile Analysis of Multidrug Resistant Pseudomonas aeruginosa isolated from Wound Infections in South West Nigeria. World Applied Science Journal, 20, 766-775.

[10] Nwachukwu, N.C., Orji, F.A. and Okike, U.M. (2009) Antibiotic Susceptibility Patterns of Bacterial Isolates from Surgical Wounds in Abia State University Teaching Hospital (ABSUTH), Aba-Nigeria. Research Journal of Medicine and Medical Sciences, 4, 575-579.

[11] Ayton, M. (1985) Wound Care: Wounds That Won’t Heal. Nursing Times, 81, 16-19.

[12] Magiorakos, A.P., Srinivasan, A., Carey, R.B., Carmeli, Y., Falagas, M.E., Giske, C.G., et al. (2011) Multidrug-Resistant, Extensively Drug-Resistant and Pandrug-Resistant Bacteria: An International Expert Proposal for Interim Standard Definitions for Acquired Resistance. Clinical Microbiology and Infectious Diseases, 18, 268-281. http://dx.doi.org/10.1111/j.1469-0691.2011.03570.x

[13] Bartoloni, A., Pallecchi, L., Benedetti, M., Fernandez, C., Vallejos, Y., Guzman, E., et al. (2006) Multidrug-Resistant Commensal Escherichia coli in Children, Peru and Bolivia. Emerging Infectious Diseases, 12, 907-913. http://dx.doi.org/10.3201/eid1206.051258

[14] von Baum, H. and Reinhard, M. (2005) Antimicrobial Resistance of Escherichia coli and Therapeutic Implications. International Journal of Medical Microbiology, 295, 503-511. http://dx.doi.org/10.1016/j.ijmm.2005.07.002

[15] Aibinu, I., Adenipekun, E. and Odugbemi, T. (2004) Emergence of Quinolone Resistance amongst Escherichia coli Strains Isolated from Clinical Infections in Some Lagos State Hospitals in Nigeria. Nigeria Journal Health Biomedical Science, 3, 73-78. http://dx.doi.org/10.4314/njhbs.v3i2.11513

[16] Celebi, A., Duran, N., Ozturk, F., Acik, L., Aslan, G. and Aslantas, O. (2007) Identification of Clinic Uropathogen Escherichia coli Isolates by Antibiotic Susceptibility, Plasmid and Whole Cell Protein Profiles. Advance Molecular Biology, 1, 31-40.

[17] Kent, P.N., Dixon, D.M., Holland, S.M. and Fauci, A.S. (2008) The Research Agenda of the National Institute of Allergy and Infectious Diseases for Antimicrobial Resistance. The Journal of Infectious Diseases, 197, 1087-1093. http://dx.doi.org/10.1086/533451

[18] Talukdar, A.D., Choudhary, M.D., Chakraborty, M. and Dutta, B.K. (2010) Phytochemical Screening and TLC Profiling of Plant Extracts Cyathea gigantea and Cyathea brunoniana. Biological and Environmental Sciences, 5, 70-74.

[19] Akueshi, C.O., Kadiri, C.O., Akueshi, E.U., Agina, S.E. and Njurukwem, C. (2002) Antimicrobial Potentials of Hyptis suaveolens Poit (Lamiaceae). Nigerian Journal of Botany, 15, 37-41.

[20] Ebi, G.C. and Ofoefule, S.I. (2000) Antimicrobial Activity of Pterocarpus osun Stems. Fitoterapia, 71, 433-435. http://dx.doi.org/10.1016/S0367-326X(00)00130-1

[21] Farooq, A., Sajid, L., Muhammad, A. and Anwarul, H.G. (2007) Moringa oleifera: A Food Plant with Multiple Medicinal Uses. Phytotherapy Research, 21, 17-25. http://dx.doi.org/10.1002/ptr.2023

[22] Burjaq, S.Z. and Shehabi, A.A. (2013) Fresh Leafy Green Vegetables Associated with Multidrug Resistant E.coli. The International Arabic Journal of Antimicrobial Agents, 3, 3.

[23] Akingbade, O.A., Damola, A.B., Shobayo, B.I., Nwanze, J.C. and Okonko, I.O. (2014) Multi-Drug Resistant (MDR) Escherichia coli among Children Suffering from Diarrhea Infections in Abeokuta, Nigeria. Researcher, 6, 11-17.

[24] Gabriel, A.F. and Onigbanjo, H.O. (2010) Phytochemical and Antimicrobial Screening of the Stem Bark Extracts of Pterocarpus erinaceus (Poir). Nigerian Journal of Basic and Applied Sciences, 18, 1-5. http://dx.doi.org/10.4314/njbas.v18i1.56835

[25] Sharma, N., Kachhawa, J.B.S., Tyagi, S., Gupta, R.S. and Sharma, K.K. (2012) In Vitro Evaluation of Antibacterial Activity of Pterocarpus marsupium Roxb. International Journal of Pharmacy and Pharmaceutical Sciences, 4, 67-68.

[26] Zee-Cheng, R.K. (1997) Anticancer Research on Loranthaceae Plants. Drugs Future, 22, 519-530.

[27] Tsuchiya, H., Sato, M., Miyazaki, T., Fujiwara, S., Tanigaki, S., Ohyama, M., Tanaka, T. and Linuma, M. (1996) Comparative Study on the Antibacterial Activity of Phytochemical Flavanones against Methicillin-Resistant Staphylococcus aureus. Journal of Ethnopharmarcology, 50, 27-34. http://dx.doi.org/10.1016/0378-8741(96)85514-0 